\title{
Identification of bacterial laccase cueO mutation from the metagenome of chemical plant sludge
}

\author{
Qingxia Yue ${ }^{1,2 \dagger}$, Yunxia Yang ${ }^{3 \dagger}$, Jintong Zhao ${ }^{2}$, Lijie Zhang ${ }^{2,4}$, Li Xu ${ }^{5}$, Xiaoyu Chu ${ }^{2}$, Xiaoqing Liu², Jian Tian² ${ }^{*}$ (i) \\ and Ningfeng $\mathrm{Wu}^{2}$
}

\begin{abstract}
Background: The metagenome contains plenty of genetic resources and can be used to search for the novel gene or mutant.

Results: In this study, the bacterial laccase gene (cueO) with single or multiple mutations was directly cloned based on the metagenome of a chemical plant sludge. An interesting mutation (G276R) was identified from those cloned mutants. The other mutants (G276N, G276Y, and G276K) with improved catalytic efficiency were identified by the saturation mutagenesis on residue G276. The optimal temperature for wild-type CueO enzyme activity was about $70{ }^{\circ} \mathrm{C}$, compared to $60^{\circ} \mathrm{C}, 50^{\circ} \mathrm{C}, 50^{\circ} \mathrm{C}$, and $30^{\circ} \mathrm{C}$ for the G276R, G276N, G276Y, and G276K mutant enzymes, respectively. The catalytic efficiency $\left(k_{\text {cat }} / K_{\mathrm{m}}\right)$ with $8 \mathrm{mmol} \mathrm{Cu}{ }^{2+}$ of the G276R, G276N, G276Y, and G276K mutants was 1.2-, 2.7-, 1.3-, and 2.7-fold, respectively, compared to the wild-type enzyme. In addition, the mutants G276R, G276N, G276Y, and G276K oxidized the carcinogen benzo[a]pyrene more efficiently compared to the wild-type enzyme.
\end{abstract}

Conclusion: All of the results indicate that G276 of CueO plays an important role in enzyme activity, and the useful mutants can be identified based on the metagenome.

Keywords: Bacterial laccase, CueO, G276K, Mutation, Metagenome

\section{Background}

Laccase (EC1.10.3.2) is a blue copper oxidase with a broad range of substrates (Kalyani et al. 2015), varying from organic to inorganic compounds such as diphenols, aromatic amines, polyphenols (Hoegger et al. 2006; Rivera-Hoyos et al. 2013; Sharma et al. 2007), and $\mathrm{Mn}^{2+}$ (Brouwers et al. 1999). The reactions of laccase are mediated by a one-electron transfer mechanism (Thurston 1994). Therefore, these enzymes can be used as biosensors for drugs and phenols (Ghindilis et al. 1992; Peter and Wollenberger 1997) and in textile dye bleaching (Claus et al. 2002), polymer synthesis (Huttermann et al. 2001), bioremediation (Murugesan 2003), pulp bleaching

\footnotetext{
*Correspondence: tianjian@caas.cn

${ }^{\dagger}$ Qingxia Yue and Yunxia Yang contributed equally to this work

${ }^{2}$ Biotechnology Research Institute, Chinese Academy of Agricultural

Sciences, Beijing 100081, China

Full list of author information is available at the end of the article
}

(Palonen and Viikari 2004), fungicides, and clarification of juices and wines (Bezerra et al. 2014).

Laccases are widely distributed among higher plants (Chen et al. 2015; Rivera-Hoyos et al. 2013), insects (Loncar et al. 2013; Hoegger et al. 2006), fungi (Eggert et al. 1996), and bacteria (Claus 2003; Si et al. 2015). Bacterial laccases play an important role in melanin production, spore coat resistance, morphogenesis, and copper detoxification (Sharma et al. 2007). Bacterial laccases have several advantages over fungal laccases (Ihssen et al. 2015; $\mathrm{Su}$ et al. 2013), such as $\mathrm{Cu}^{2+}$ resistance (Hullo et al. 2001; Komori and Higuchi 2015) and pH (Ruijssenaars and Hartmans 2004) and thermal (Suzuki et al. 2003) stability. In addition, bacterial laccases do not need to be glycosylated and so have considerable potential for use in industrial applications (Sharma et al. 2007).

The majority of microbes cannot be cultured by traditional methods. The metagenome contains a large 
number of functional genes. Therefore, metagenomic analyses facilitate the discovery of novel genes in biological communities by overcoming the limitations of cultivation-dependent approaches (Guazzaroni et al. 2015; Leis et al. 2013). Kellner et al. analyzed the diversity of bacterial laccase genes in samples from forests and grasslands and found 16 distinct sequence-type clades of bacterial laccase (Kellner et al. 2008). Kellenberger et al. evaluated the spatial distribution and function of fungal laccase genes from a forest cambisol (Kellenberger 2001). These studies have indicated that the metagenome contains many genetic resources.

In addition to the various laccase genes, the metagenome may also contain many useful mutations of a target laccase gene. In this study, we refer to an extensively studied laccase gene cueo from E. coli $\mathrm{K} 12$ as the wild type (Zeng et al. 2011). Many interesting mutants with high activity were identified from the metagenome of bacteria in chemical plant sludge. The ability of the $\mathrm{CueO}$ protein and its mutants to degrade benzo[ $\alpha]$ pyrene, a mutagenic and highly carcinogenic environmental polycyclic aromatic hydrocarbon (PAH), was evaluated (Zhao et al. 2013). The results indicate that the cloned cueO mutants could catalyze transformation of PAHs, similar to the function of fungal laccase from Trametes versicolor (Zeng et al. 2011, 2016; Hullo et al. 2001; Roberts et al. 2002). Therefore, useful mutants can be identified from the metagenome, increasing our understanding of the genetic diversity of the functional gene.

\section{Methods}

\section{Chemicals and media}

Luria-Bertani (LB) medium contained 1\% peptone, $0.5 \%$ yeast extract, and $1 \% \mathrm{NaCl}(\mathrm{pH} 7.0)$. Escherichia coli strain BL21 (DE3) and DNA polymerase were purchased from Qiangen (Beijing, China), and T4 DNA ligase and the BamHI and HindIII restriction enzymes were from New England Biolabs. Autoinduction medium was purchased from Biolab.

\section{Extraction of a chemical plant sludge metagenome}

The metagenome was extracted from a chemical plant sludge in Jiangxi Province, China. Cells were lysed by incubation in $20 \mathrm{~mL}$ cetyltrimethylammonium bromide containing $50 \mu \mathrm{L}$ protease $(20 \mathrm{mg}$ protease per milliliter) at $37^{\circ} \mathrm{C}$ with shaking at $250 \mathrm{rpm}$ for $30 \mathrm{~min}$. Then, $5 \mathrm{~mL} 2 \%$ SDS was added, followed by incubation for $2 \mathrm{~h}$ at $65^{\circ} \mathrm{C}$ to denature protein and freeze thawing to enhance cell lysis. Protein was extracted using phenol/chloroform/isopentanol (25:24:1). DNA was precipitated by addition of a 0.6 -fold volume of isopropyl alcohol followed by washing in $70 \%$ ethanol to remove basic ions.

\section{Cloning of the cueO gene}

The cueO gene fragment was amplified from the sludge metagenome using the Taq Plus DNA polymerase with the forward primer cueO-F, which contains a unique $B a m H I$ restriction site at the start codon of the open reading frame, and the reverse primer cueO-R, which contains a HindIII restriction site. The PCR conditions were as follows: an initial denaturing step at $95{ }^{\circ} \mathrm{C}$ for 5 min followed by 30 cycles of $95{ }^{\circ} \mathrm{C}$ for $30 \mathrm{~s}, 60{ }^{\circ} \mathrm{C}$ for $30 \mathrm{~s}$, and $72{ }^{\circ} \mathrm{C}$ for $1 \mathrm{~min} 40 \mathrm{~s}$. The PCR products and the vector were digested with $B a m \mathrm{HI}$ and HindIII and purified using the Axyprep DNA Kit (Axygen) and PCR Purification Kit (Qiangen). The purified product was ligated into the pET-30a $(+)$ vector overnight using T4 DNA ligase at $16{ }^{\circ} \mathrm{C}$. Escherichia coli BL21 (DE3) was transformed with the ligation mixture, and transformants were selected in LB medium containing $50 \mu \mathrm{g}$ kanamycin per milliliter. The recombinant plasmid was verified by PCR, and positive clones were sequenced.

\section{Expression and purification of $\mathrm{CueO}$ protein}

Escherichia coli BL21 (DE3) cells harboring the recombinant gene were cultured in $3 \mathrm{~mL}$ LB medium supplemented with kanamycin $(50 \mu \mathrm{g} / \mathrm{mL})$ at $30{ }^{\circ} \mathrm{C}$ with shaking at $120 \mathrm{rpm}$ to an $\mathrm{OD}_{600}$ of 0.6 . Then, $0.1 \mathrm{mM}$ isopropyl- $\beta$-D-thiogalactopyranoside and $0.25 \mathrm{mM}$ $\mathrm{CuCl}_{2}$ were added to the culture medium, and the temperature was reduced to $25{ }^{\circ} \mathrm{C}$. Incubation was continued for a further $4 \mathrm{~h}$, during which microaerobic conditions were achieved by switching off the shaking function (Nasoohi et al. 2013; Brander et al. 2014; Durao et al. 2008). Cells were harvested after a further $20 \mathrm{~h}$ of growth by centrifugation at $8000 \mathrm{~g}$ for $10 \mathrm{~min}$ (Durao et al. 2008). The pellets were resuspended in $50 \mathrm{mM}$ Tris/ $\mathrm{HCl}$ buffer $(\mathrm{pH} 8.0)$. The cells were disrupted by sonication on ice, and debris was removed by centrifugation at $4{ }^{\circ} \mathrm{C}$ and $13,000 \mathrm{~g}$ for $5 \mathrm{~min}$. The recombinant proteins were purified with Ni-NTA Superflow (QIAGEN, U.S.) according to the manufacturer's instructions. The concentration of the expressed laccase protein was determined using a 2100 BioAnalyzer instrument (Agilent Technologies, Palo Alto, CA).

\section{Single-point mutation and G276 saturation mutagenesis}

To evaluate the expression and specific activity of mutants, we generated single-point mutations in the residues that differ from the sequence of the wild type in the mutants $M 1$ to $M 6$ using the PCR mutagenesis strategy (Kirsch and Joly 1998). The primers cueO28-F, сиеO48-F, сиеO63-F, сиеO116-F, сиеO135-F, сиеO250-F, сиеO276-F, сиеО318-F, сиеO385-F, сиеO390-F, сиеO413F, сиеO444-F, сиеO464-F, сиеO471-F, and сиеOM-R were used to generate the single-point mutants. Saturation 
mutagenesis of G276 was performed using the primers G276-F and cueOM-R. A saturation mutagenesis library at site G276 was constructed, and the mutation site was designed using the method of NNK degeneracy $(\mathrm{N}$, adenine/cytosine/guanine/thymine; $K$, guanine/thymine) to encode all 20 amino acids (Tian et al. 2013). PCR products were ligated into the $\mathrm{pET}-30 \mathrm{a}(+)$ vector and transformed into BL21 (DE3) cells. The mutants were incubated in 96-well plates in an autoinduction medium at $30{ }^{\circ} \mathrm{C}$ with shaking at $200 \mathrm{rpm}$ (Ukkonen et al. 2013; $\mathrm{Li}$ et al. 2011). After $24 \mathrm{~h}$, the cells were harvested by centrifugation at $12,000 \mathrm{~g}$ for $1 \mathrm{~min}$, and the pellets were resuspended in $20 \mathrm{mM}$ Tris/HCl buffer ( $\mathrm{pH} 8.0$ ) containing $20 \%$ sucrose, and the mixture was placed on ice for $30 \mathrm{~min}$ and centrifuged at $12,000 \mathrm{~g}$ for $15 \mathrm{~min}$. The pellets were resuspended in $20 \mathrm{mM}$ Tris/ $\mathrm{HCl}$ buffer ( $\mathrm{pH} \mathrm{8.0)}$ and placed on ice for $1 \mathrm{~h}$. The cell suspensions then were centrifuged at $12,000 \mathrm{~g}$ for $20 \mathrm{~min}$, and enzyme activity in the supernatants was assayed at $37^{\circ} \mathrm{C}$ and $\mathrm{pH} 4.5$.

\section{Laccase activity}

Laccase activity was assayed at $60^{\circ} \mathrm{C}$ using 2,2-azino-di(3-ethylbenzthiazoline-sulfonate) (ABTS) as substrate. The assay mixture contained $200 \mu \mathrm{L} 5 \mathrm{mM}$ ABTS and $750 \mu \mathrm{L} 50 \mathrm{mM}$ citrate/phosphate. The increase in absorbance due to the oxidation of ABTS at $420 \mathrm{~nm}$ was measured $\left(\varepsilon_{420}=36,000 \mathrm{M}^{-1} \mathrm{~cm}^{-1}\right)$. One unit was defined as the amount of enzyme that oxidized $1 \mu \mathrm{mol}$ of substrate per minute.

\section{Optimization of reaction conditions}

The optimum temperature was examined at $\mathrm{pH} 4.5$ in the presence of $1 \mathrm{mM}$ ABTS at $0-100{ }^{\circ} \mathrm{C}$. A mixture of ice and water was used to maintain the temperature at $0{ }^{\circ} \mathrm{C}$. Enzyme activity at $\mathrm{pH} 2.1-7.5$ was evaluated. ABTS and $0.1 \mathrm{M}$ citrate phosphate buffer were incubated at the optimum temperature of each protein 2 min before addition of enzyme.

\section{Enzyme kinetics}

Kinetic analyses were performed using $0.2-10 \mathrm{mM}$ ABTS, $8 \mathrm{mM} \mathrm{Cu}^{2+}$, and citrate phosphate buffer after incubating at the optimum temperature for $2 \mathrm{~min}$. The reaction was initiated by addition of $50 \mu \mathrm{L}$ purified enzyme. Each test was carried out in at least three replicates. The $K_{\mathrm{m}}$ and $k_{\text {cat }}$ values were calculated by nonlinear regression using GraphPad Prism 5.0 (GraphPad Software Inc., La Jolla, CA).

\section{Differential scanning calorimetry}

$T_{m}$ (melting temperature) values of $\mathrm{CueO}$ and its mutants were determined by differential scanning calorimetry (General Electric Company, Louisville, KY, USA) using $\geq 400 \mu \mathrm{g}$ of sample per milliliter (Jian Tian et al. 2015). The scanning temperature was from 20 to $110{ }^{\circ} \mathrm{C}$ in the PBS buffer ( $\mathrm{pH}$ 7.4).

\section{Oxidation of benzo[a]pyrene by $\mathrm{CueO}$ and its mutants}

Oxidation of benzo[ $\alpha]$ pyrene by $\mathrm{CueO}$ and its mutants was studied at $\mathrm{pH} 3.5$ by reacting $0.3 \mathrm{mg}$ benzo[ $\alpha]$ pyrene per liter with $200 \mu \mathrm{g}$ laccase per milliliter $\left(30{ }^{\circ} \mathrm{C}\right)$ or $4 \mu \mathrm{g}$ laccase per milliliter $\left(60^{\circ} \mathrm{C}\right)$. To facilitate degradation, we added ABTS $(0.5 \mathrm{mM})$ to a $200 \mu \mathrm{L}$ reaction system. After incubation at $\mathrm{pH} 3.5$ for $12 \mathrm{~h}$ at 30 and $60{ }^{\circ} \mathrm{C}$, the reaction was terminated by incubation for $1 \mathrm{~h}$ in an ice-water mixture, and the mixture was diluted by addition of $800 \mu \mathrm{L}$ acetonitrile. Benzo[ $\alpha]$ pyrene in the reaction system was determined quantitatively using a Shimadzu LC-20AB high-performance liquid chromatography system equipped with a fluorescence detector (RF-10AxL). Benzo[ $\alpha]$ pyrene was separated on a $\mathrm{C}_{18}$ column $(4.6 \times 250 \mathrm{~mm}, 5 \mu \mathrm{m}$; Waters, USA) by gradient elution at a constant flow rate of $1 \mathrm{~mL} / \mathrm{min}$ with a mobile phase A (acetonitrile) to mobile phase $B$ ratio of 98:2. The amount of benzo $[\alpha]$ pyrene was determined using a fluorescence detector with excitation and emission wavelengths of 297 and $408 \mathrm{~nm}$, respectively.

\section{Results and discussion}

\section{Screening the mutants from the metagenome}

The metagenome was extracted from the sludge of a chemical plant in Jiangxi Province, China. Primers (cueO-F and cueO-R in Additional file 1: Table S1) were designed to amplify the cueO gene. The PCR product was $1467 \mathrm{bp}$ in length, and contained a termination codon. The PCR product was digested with BamHI and HindIII, then ligated into the pET-30a $(+)$ vector and 30 different positive clones were sequenced. Based on the sequencing results, there were 16 sequences, which are identical to cueO (NCBI gene ID: 947736) of E. coli K12 and referred as the wild-type cueo in this study. In addition to the wild-type cueO, we also identified 14 cueO mutants, including eight mutants containing the synonymous mutations and six mutants containing the non-synonymous mutations. Some of the mutants contained multiple mutations, as shown in Fig. 1. The fidelity of the PCR polymerase was also evaluated. The same primers (сuеO-F and cueO-R in Additional file 1: Table S1) were used in the PCR with the wild-type cueO gene as the PCR template. The PCR product was digested with BamHI and HindIII, then ligated into the pET$30 \mathrm{a}(+)$ vector and 30 different positive clones were also sequenced. The sequencing results indicated that the PCR polymerase had very high fidelity, as the 30 different positive clones containing the $\mathrm{cueO}$ gene did not 
contain any mutations. Therefore, the сиеO mutations detected in the metagenome were not due to errors during PCR amplification.

\section{Enzyme activity}

The 6 non-synonymous mutants (M-1 to $M-6)$ and wildtype cueO were expressed in E. coli BL21(DE3), and their activities in the cell lysate were determined. The $M-2$ mutant showed the highest activity in cell lysate. However, the activities of the M-1, M-3, M-4, M-5, and M-6 mutants in cell lysate were lower than that of wild-type CueO (Fig. 2).

As the six mutants contained multiple mutations, we generated enzymes with only single-point mutations, expressed them in E. coli, and determined their activity. To evaluate the activity of the mutants via high-throughput screening, cells containing the mutants were broken by osmotic pressure (Nossal and Heppel 1966). The activity in the supernatant of all mutants was measured under the same experimental conditions $(\mathrm{pH} 4.5$ and $37^{\circ} \mathrm{C}$ ). As shown in Fig. 3, the G276R mutant exhibited about sevenfold higher activity than wild-type CueO. The activity of the other mutants was similar to that of wild-type CueO. Therefore, the residue G276 of CueO plays an important role in enzyme activity. The tool of CDD (Conserved Domain Database, CDD) in NCBI (Marchler-Bauer et al. 2015) was used to detect the conserved residues in CueO. The residue G276 in Cueo was not conserved and could be mutated to the other amino acids. In this study, the expression host strain is E. coli BL21(DE3) which contains the gene of cueo. However, the activity of the expressed Cueo from the native host

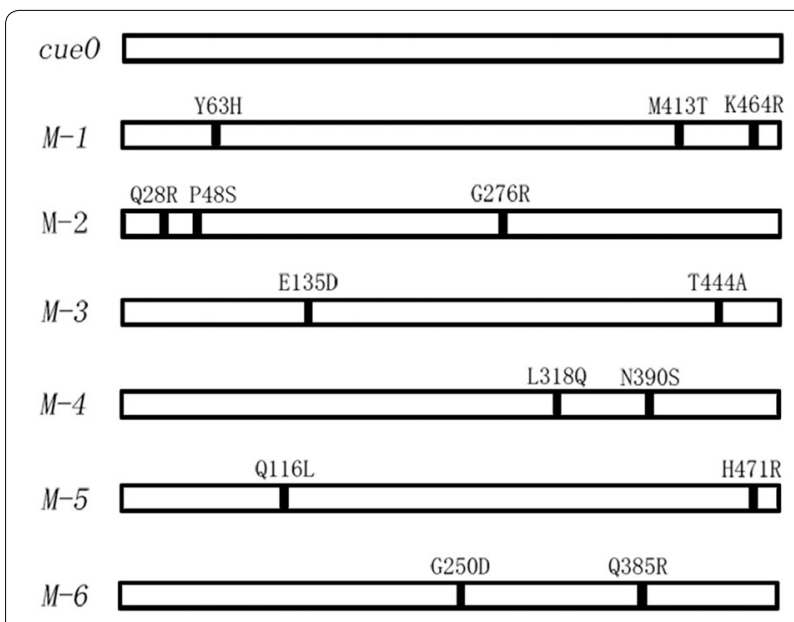

Fig. 1 cueO mutants cloned from the soil metagenome. cueO is the wild-type gene. $M-1, M-2, M-3, M-4, M-5$, and $M-6$ represent the different mutants. These genes were amplified by the primers cueO-F and cueO-R, and gene mutants are shown by vertical bars

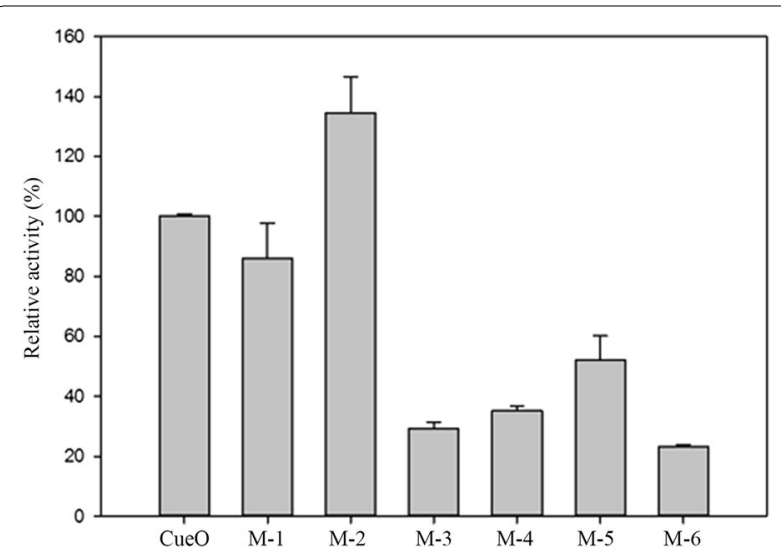

Fig. 2 Relative laccase activity of the CueO mutants compared to wild type at $\mathrm{pH} 4.5$ and $60{ }^{\circ} \mathrm{C}$. The relative laccase activity in the supernatants was determined using standard enzyme assays and shown on the $y$-axis. Enzyme activity is expressed as the mean of three samples, and error bars indicate standard deviation

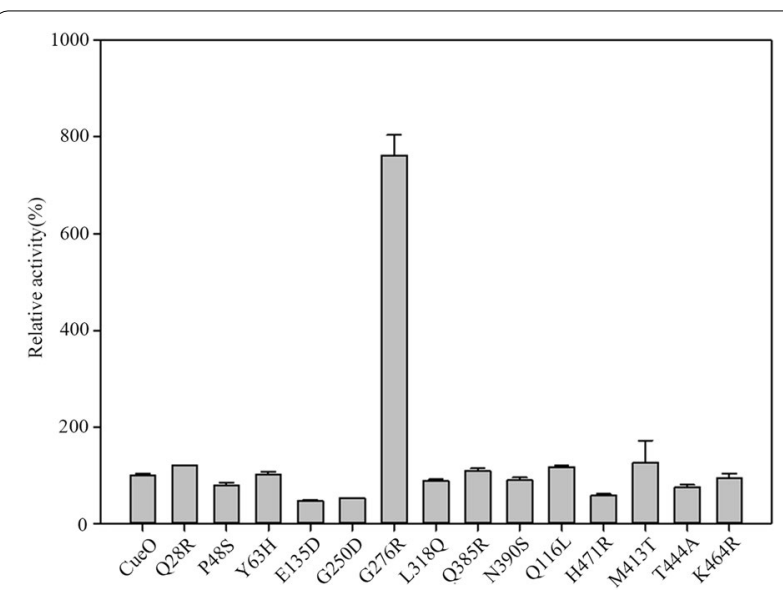

Fig. 3 Relative laccase activity of single-point mutants of $\mathrm{CueO}$ compared to wild type at $\mathrm{pH} 4.5$ and $60^{\circ} \mathrm{C}$. The activity of the G276R mutant was about sevenfold higher than that of the wildtype enzyme. The relative laccase activity in the supernatants was determined using standard enzyme assays and shown on the $y$-axis. Enzyme activity is expressed as the mean of three samples, and error bars indicate standard deviation

E. coli BL21(DE3) is difficult to be measured with the standard method, as the expressed amount of the enzyme from the native host is very low. In addition, the expression vector pET30 was used to express the gene cueo and the mutants. Therefore, the expression host E. coli BL21(DE3) was selected in this study.

\section{Saturation mutagenesis of residue G276}

As the residue G276 was not conserved and related to the catalytic efficiency, a saturation mutagenesis 
library on the residue G276 was constructed. The wild-type cueO gene and mutants were expressed in E. coli BL21 (DE3) using the pET expression system. Over 150 clones were subjected to screening for laccase activity higher than that of wild-type CueO. In addition to G276R, three other mutants (G276K, G276Y, and G276N) were identified and exhibited activities superior to that of the wild type. At $\mathrm{pH} 4.5$ and $37{ }^{\circ} \mathrm{C}$, the activity of $\mathrm{G} 276 \mathrm{~N}$ was threefold higher than the wild-type enzyme and the other mutants were twofold higher than that of the wild-type enzyme (Fig. 4).

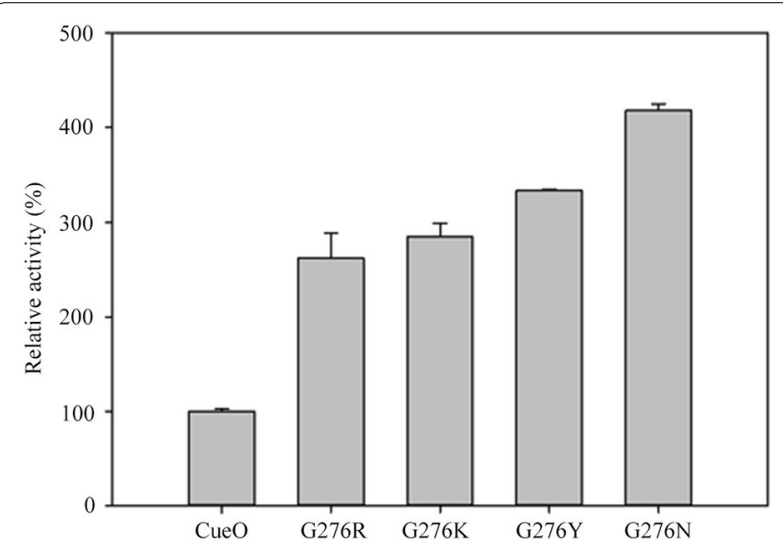

Fig. 4 Relative laccase activity of the G276K, G276Y, and G276N mutants compared to wild-type $\mathrm{CueO}$ at $\mathrm{pH} 4.5$ and $60^{\circ} \mathrm{C}$. The relative laccase activity in the supernatants was determined using standard enzyme assays and shown on the $y$-axis. Enzyme activity is expressed as the mean of three samples, and error bars indicate standard deviation

\section{Optimum temperature and $\mathrm{pH}$}

Fungal laccases have optimal temperatures of $30-55{ }^{\circ} \mathrm{C}$; however, bacterial laccases tend to show activity at higher temperatures (Rivera-Hoyos et al. 2013; Sharma et al. 2007). The wild-type and mutant proteins were expressed, purified, and migrated as a single band at an apparent molecular mass of $\sim 60 \mathrm{kDa}$ on SDS-PAGE (Additional file 2: Figure S1). The optimal temperatures of the wild-type and mutant $\mathrm{CueO}$ were measured. The optimum temperature of wild-type $\mathrm{CueO}$ was $\sim 70{ }^{\circ} \mathrm{C}$, compared to 60,50 , and $30{ }^{\circ} \mathrm{C}$ for the G276R, G276N, and G276K mutants, respectively (Fig. 5a). Notably, the mutants exhibited higher activity at $0{ }^{\circ} \mathrm{C}$ than that of the wild type. The $T_{\mathrm{m}}$ values of wild-type, G276R, G276K, G276Y, and G276N CueO proteins were determined by differential scanning calorimetry (DSC) to be 80.9, 76.2, 75.6, 77.4, and $75.2{ }^{\circ} \mathrm{C}$, respectively. Therefore, mutation of G276 affected the stability of the enzyme. However, as the G276R, G276K, G276Y, and G276N mutants exhibited $T_{\mathrm{m}}$ values $>75^{\circ} \mathrm{C}$, they were stable proteins. The wild-type and mutant $\mathrm{CueO}$ enzymes exhibited the highest activity under acidic conditions (Fig. 5b). Moreover, the optimum pHs of the G276K, G276Y, and G276N mutants were lower than that of the wild type. At $\mathrm{pH} 2.5$, the G276K, G276Y, and G276N mutants exhibited $\sim 100 \%$ of their maximum activities. Therefore, these enzymes should be used under acidic conditions.

\section{Kinetic parameters}

We determined the kinetic properties of the purified enzymes (Table 1$)$. The catalytic efficiencies $\left(k_{\mathrm{cat}} / K_{\mathrm{m}}\right)$ of the mutants under optimum conditions (including the optimal temperature and optimal $\mathrm{pH}$ ) were higher than
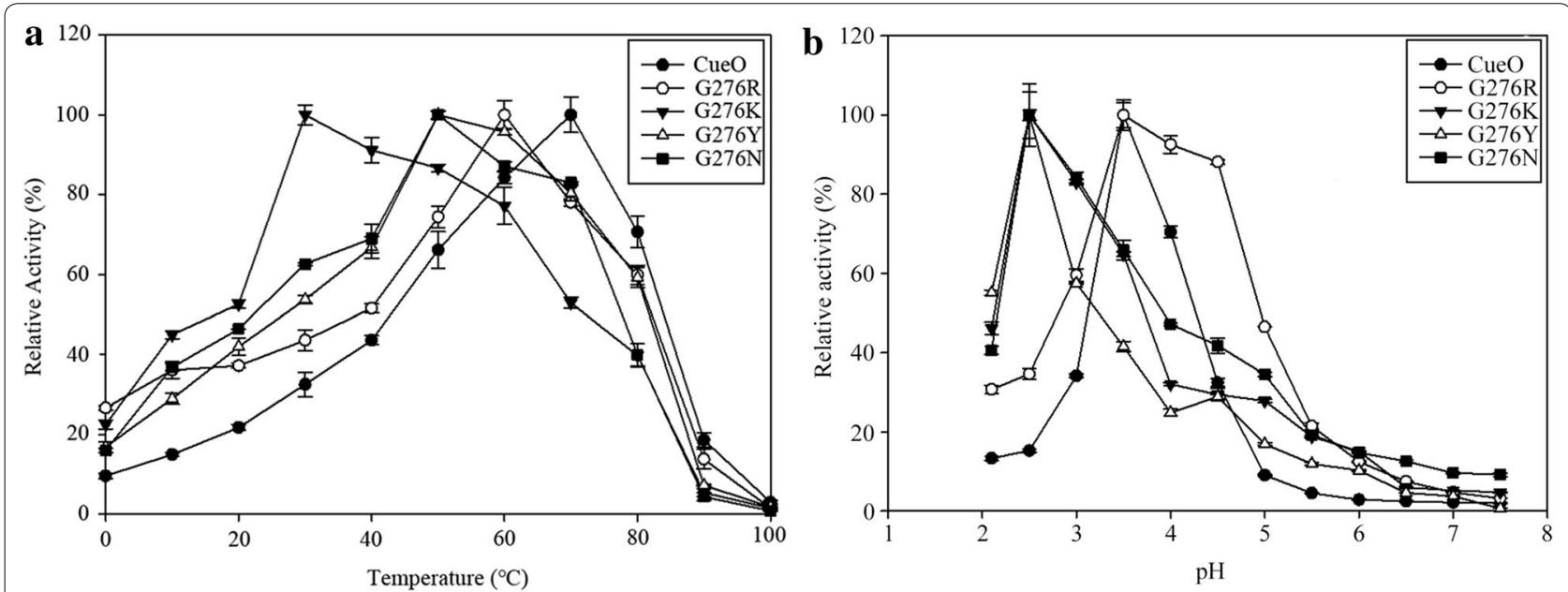

Fig. 5 Optimum temperature $(\mathbf{a})$ and $\mathrm{pH}(\mathbf{b})$ of recombinant $\mathrm{CueO}$ and its mutants. To measure the optimum temperature, the $\mathrm{pH}$ of the experimental buffer was maintained at 4.5. To measure the optimum pH, the optimum temperature of the corresponding enzyme was maintained 
Table 1 Catalytic parameters of wild-type CueO and mutants

\begin{tabular}{llll}
\hline & $\boldsymbol{K}_{\mathbf{m}}(\boldsymbol{\mu m o l} / \mathbf{L})$ & $\boldsymbol{k}_{\mathbf{c a t}}\left(\mathbf{s}^{-\mathbf{1}}\right)$ & $\boldsymbol{k}_{\mathbf{c a t}} / \boldsymbol{K}_{\mathbf{m}}$ \\
\hline CueO & $292.5 \pm 40.0$ & $31.7 \pm 0.8$ & $0.108 \pm 0.018$ \\
G276R & $493.3 \pm 60.6$ & $60.8 \pm 1.8$ & $0.123 \pm 0.019$ \\
G276K & $219.0 \pm 40.2$ & $63.1 \pm 2.6$ & $0.288 \pm 0.065$ \\
G276Y & $269.4 \pm 29.5$ & $38.3 \pm 1.1$ & $0.142 \pm 0.020$ \\
G276N & $123.7 \pm 16.8$ & $35.0 \pm 1.0$ & $0.283 \pm 0.046$ \\
\hline
\end{tabular}

The kinetic parameters were measured under optimal temperatures and $\mathrm{pHs}$ of CueO, G276R, G276K, G276Y, and G276N $\left(70,60,30,50\right.$, and $50{ }^{\circ} \mathrm{C}$ and 3.5 , $3.5,2.5,2.5$, and 2.5 , respectively). The experiments were performed using ABTS $(0.2-10 \mathrm{mM}), 8 \mathrm{mM} \mathrm{Cu}^{2+}$, and citrate phosphate buffer. Measurements were performed using standard enzyme assays in three replications. The data were fit using GraphPad Prism 5.0 (GraphPad Software Inc.)

that of the wild-type enzyme. Therefore, the G276 residue is important for enzyme activity.

The active sites in laccase include at least four $\mathrm{Cu}$ atoms and can be classified into three types according to their spectroscopic properties: type 1 (T1), type 2 (T2), and type 3 (T3); the two types of $\mathrm{Cu}$ sites (T2 and T3) form the trinuclear copper center (Malmstrom 1982). The substrate is oxidized by the T1 copper atom and the electron is conducted through the core of the protein to the T2/T3 site, where four electrons are used to reduce dioxygen to water (Solomon et al. 2008). Mutations at $\mathrm{E}^{106}, \mathrm{Cys}^{500}$, $\mathrm{Asp}^{112}$, and $\mathrm{Glu}^{506}$ of CueO can affect the electronic state of the trinuclear copper center and enzyme activity (Kataoka et al. 2009; Komori et al. 2013; Nasoohi et al. 2013). In this study, we identified CueO mutants at another position (G276) with high activity; in particular, the G276R mutant exhibited greater activity than the wild-type protein. Structural analyses revealed that the G276 residue is located near the active site of the enzyme and close to the methionine-rich helix (residues 329-343) (Prins et al. 2015; Roberts et al. 2002) (Fig. 6). Some studies showed the methionine-rich helix region to be largely helical and to cover the substrate-binding region (Roberts et al. 2002; Singh et al. 2011). Therefore, the mutation on G276 may alter the conformation of the methionine-rich helix region. The structural changes may promote the substrate binding and increase of the mutant in catalytic activity. However, this hypothesis should be verified by determination of the crystal structures of the CueO mutants in the future study.

\section{Oxidation of benzo[a]pyrene by CueO and its mutants}

The CueO laccase and mutants thereof were capable of oxidizing benzo[ $\alpha]$ pyrene (Fig. 7a, b). Both the wild-type and mutant $\mathrm{CueO}$ proteins exhibited higher degradative activity at $60{ }^{\circ} \mathrm{C}$ than at $30{ }^{\circ} \mathrm{C}$. The mutants exhibited higher oxidation activity than the wild-type enzyme at 30 and $60{ }^{\circ} \mathrm{C}$. Therefore, the mutants have considerable potential for applications involving benzo[ $\alpha]$ pyrene degradation. In this study, the two substrates (ABTS and benzo[ $\alpha]$ pyrene) were selected to evaluate the catalytic efficiency of the wild-type $\mathrm{CueO}$ and mutants. There are lots of substrates for the laccase. If the laccase could oxidize the substrate ABTS with high efficiency, the laccase usually has the good catalytic efficiency to other substrates (Camarero et al. 2012; Prins et al. 2015). In the
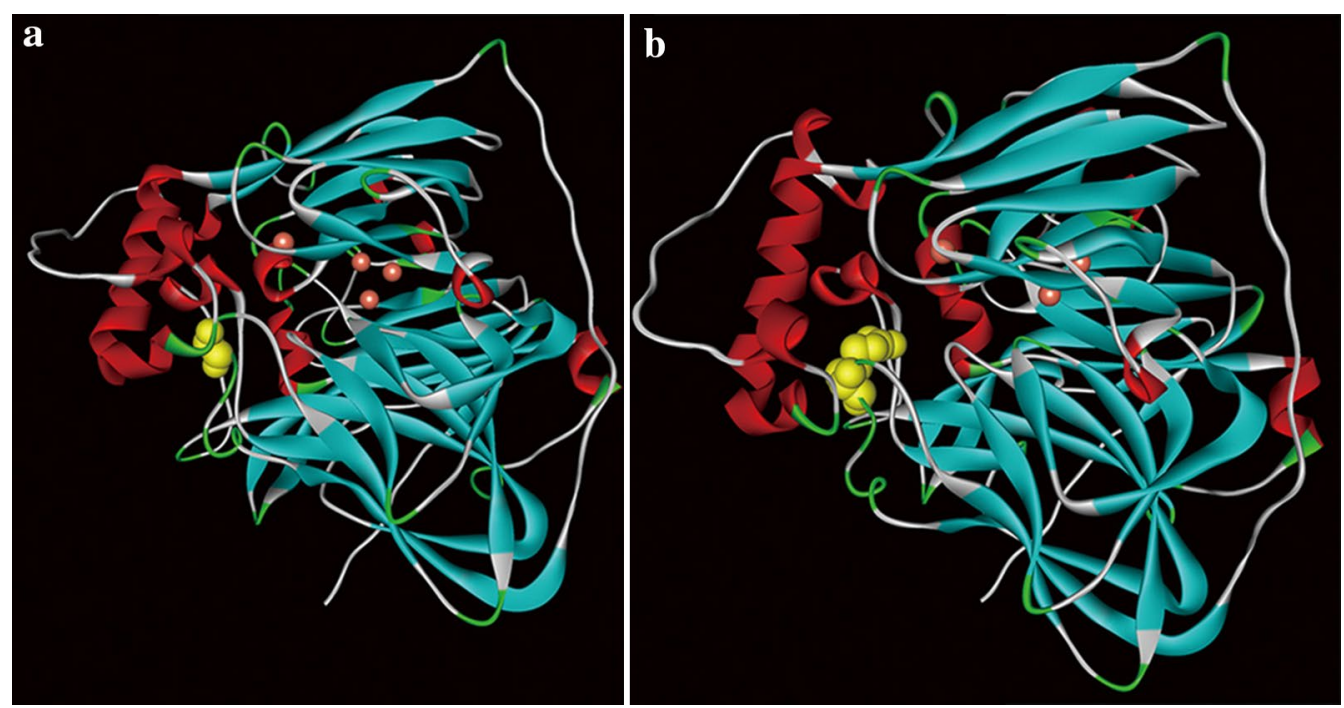

Fig. 6 Structure of wild-type CueO and its mutant (G276R). The Protein Data Bank ID of the wild-type CueO is 3OD3. The mutant G276R was constructed based on the structure of wild-type CueO, which was modeled using the Discovery Studio 2.5 .5 software. The amino acids with the yellow color are the wild G276 (panel a) and R276 (panel b) 

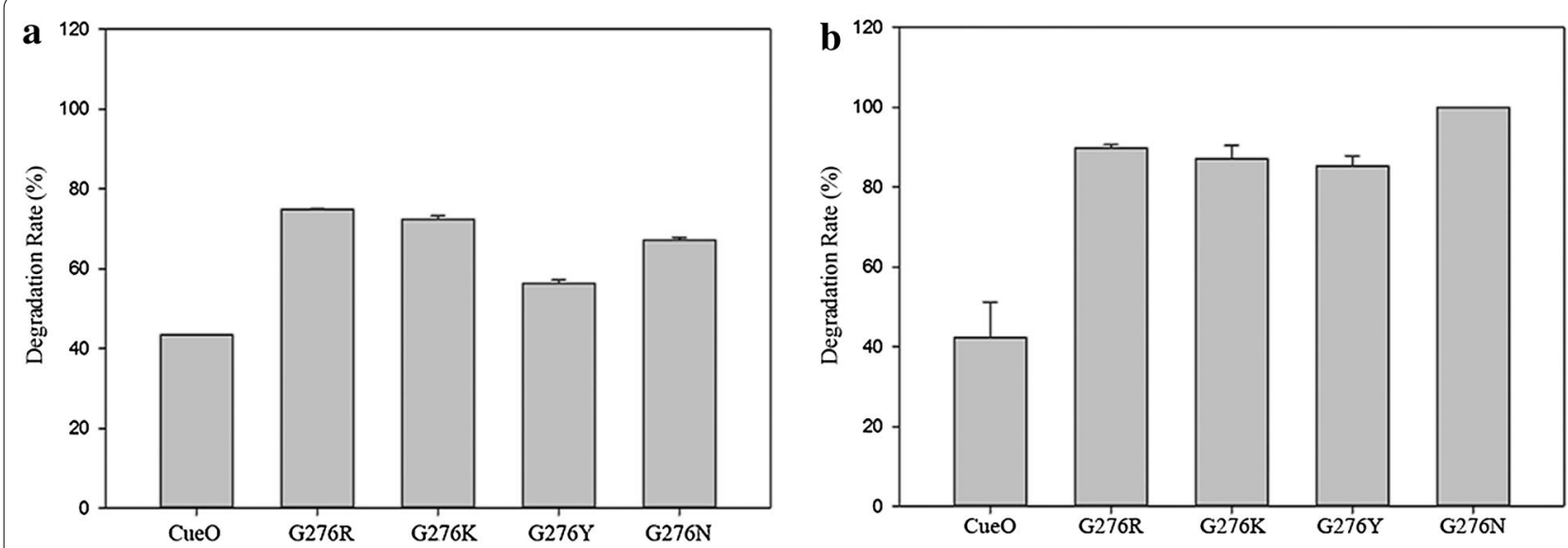

Fig. 7 Oxidation of benzo[a]pyrene by $\mathrm{CueO}$ and its mutants at $\mathbf{a p H} 3.5$ and $30^{\circ} \mathrm{C}$, and $\mathbf{b} \mathrm{pH} 3.5$ and $60^{\circ} \mathrm{C}$. The reaction system contains $0.3 \mathrm{ppm}$ benzo[a]pyrene and $200 \mu \mathrm{g}$ laccase per milliliter $\left(30^{\circ} \mathrm{C}\right)$ or $4 \mu \mathrm{g}$ laccase per milliliter $\left(60^{\circ} \mathrm{C}\right)$ and $\mathrm{ABTS}(0.5 \mathrm{mM})$

future study, the other substrates will be used to evaluate the performance of those mutants.

\section{Conclusion}

The metagenome contains plenty of genetic resources and can be used to search for the novel gene or mutation (Pardo and Camarero 2015). In this study, the mutation G276R of laccase CueO was identified based on the metagenome of a chemical plant sludge, which showed better catalytic properties compared to the wild type. Other mutants (G276K, G276Y, and G276N) at this site were also screened from the saturated mutation library and exhibited better catalytic properties compared to the wild type. The G276R, G276N, G276Y, and G276K

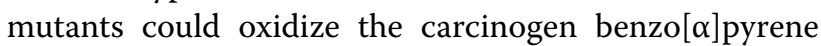
more efficiently compared to the wild-type enzyme. This study found a novel cueO residue G276 that can affect enzyme activity, and some mutants at that residue could be useful for biological remediation.

\section{Additional files}

\section{Additional file 1: Table S1. The primers used in this study.}

Additional file 2: Figure S1. Sodium dodecyl sulfate-polyacrylamide gel electrophoresis of recombinant $\mathrm{CueO}$ and its mutants produced in E. coli BL21(DE3). Lane 1 The wild-type CueO. Lane 2 The mutant G276R. Lane 3 The mutant G276K. Lane 4 The mutant G276Y. Lane 5 The mutant G276N, the proteins were purified through the Ni-chelating affinity chromatography.

\section{Author details}

${ }^{1}$ College of Life Science and Technology, Jinan University, Guangzhou 510632, China. ${ }^{2}$ Biotechnology Research Institute, Chinese Academy of Agricultural Sciences, Beijing 100081, China. ${ }^{3}$ Institute of Quality Standards and Testing Technology for Agro-products, Chinese Academy of Agricultural Sciences, Beijing 100081, China. ${ }^{4}$ College of Life Sciences, Agricultural University of Hebei, Baoding 071001, China. ${ }^{5}$ Environmental Protection Research Institute of Light Industry, Beijing 100037, China.

\section{Acknowledgements}

Not applicable.

\section{Competing interests}

The authors declare that they have no competing interests.

\section{Availability of data and materials}

All data generated or analyzed during this study are included in this article.

\section{Consent for publication}

All authors approved the consent for publishing the manuscript to bioresources and bioprocessing. There is no competing interest for any of the author regarding the submission of this manuscript.

Ethics approval and consent to participate Not applicable.

\section{Funding}

This work was supported by the National High Technology Research and Development Program of China (863 Program, 2013AA102804).

\section{Publisher's Note}

Springer Nature remains neutral with regard to jurisdictional claims in published maps and institutional affiliations.

Received: 19 September 2017 Accepted: 11 November 2017 Published online: 17 November 2017

\section{References}

Bezerra TMDS, Bassan JC, Santos VTDO, Ferraz A, Monti R (2014) Covalent immobilization of laccase in green coconut fiber and use in clarification of apple juice. Process Biochem 50(3):417-423 
Brander S, Mikkelsen JD, Kepp KP (2014) Characterization of an alkali- and halide-resistant laccase expressed in E. coli: CotA from Bacillus clausii. PLOS ONE 9(6):e99402

Brouwers GJ, Vrind JPMD, Corstjens PLAM, Jong VD, Cornelis P, Baysse C (1999) cumA, a gene encoding a multicopper oxidase, is involved in $\mathrm{Mn}\{$ sup $2+\}$ oxidation in Pseudomonas putida GB1. Appl Environ Microbiol 65(4):1762-1768

Camarero S, Pardo I, Canas Al, Molina P, Record E, Martinez AT et al (2012) Engineering platforms for directed evolution of Laccase from Pycnoporus cinnabarinus. Appl Environ Microbiol 78(5):1370-1384

Chen B, Xu WQ, Pan XR, Lu L (2015) A novel non-blue laccase from Bacillus amyloliquefaciens: secretory expression and characterization. Int J Biol Macromol 76:39-44

Claus H (2003) Laccases and their occurrence in prokaryotes. Arch Microbiol 179(3):145-150

Claus H, Faber G, Konig H (2002) Redox-mediated decolorization of synthetic dyes by fungal laccases. Appl Microbiol Biotechnol 59(6):672-678

Durao P, Chen Z, Fernandes AT, Hildebrandt P, Murgida DH, Todorovic S et al (2008) Copper incorporation into recombinant CotA laccase from Bacillus subtilis: characterization of fully copper loaded enzymes. J Biol Inorg Chem 13(2):183-193

Eggert C, Temp U, Eriksson KE (1996) The ligninolytic system of the white rot fungus Pycnoporus cinnabarinus: purification and characterization of the laccase. Appl Environ Microbiol 62(4):1151-1158

Ghindilis AL, Gavrilova VP, Yaropolov AI (1992) Laccase-based biosensor for determination of polyphenols: determination of catechols in tea. Biosens Bioelectron 7(2):127-131

Guazzaroni ME, Silva-Rocha R, Ward RJ (2015) Synthetic biology approaches to improve biocatalyst identification in metagenomic library screening. Microb Biotechnol 8(1):52-64

Hoegger PJ, Kilaru S, James TY, Thacker JR, Kües U (2006) Phylogenetic comparison and classification of laccase and related multicopper oxidase protein sequences. Febs J 273(10):2308-2326

Hullo MF, Moszer I, Danchin A, Martin-Verstraete I (2001) CotA of Bacillus subtilis is a copper-dependent laccase. J Bacteriol 183(18):5426-5430

Huttermann A, Mai C, Kharazipour A (2001) Modification of lignin for the production of new compounded materials. Appl Microbiol Biotechnol 55(4):387-394

Ihssen J, Reiss R, Luchsinger R, Thony-Meyer L, Richter M (2015) Biochemical properties and yields of diverse bacterial laccase-like multicopper oxidases expressed in Escherichia coli. Sci Rep 5:10465

Kalyani D, Tiwari MK, Li J, Kim SC, Kalia VC, Kang YC et al (2015) A highly efficient recombinant laccase from the yeast Yarrowia lipolytica and its application in the hydrolysis of biomass. PLoS ONE 10(3):e0120156

Kataoka K, Sugiyama R, Hirota S, Inoue M, Urata K, Minagawa Y et al (2009) Four-electron reduction of dioxygen by a multicopper oxidase, CueO, and roles of Asp112 and Glu506 located adjacent to the trinuclear copper center. J Biol Chem 284(21):14405-14413

Kellenberger E (2001) Exploring the unknown. The silent revolution of microbiology. EMBO Rep 2(1):5-7

Kellner H, Luis P, Zimdars B, Kiesel B, Buscot F (2008) Diversity of bacterial laccase-like multicopper oxidase genes in forest and grassland Cambisol soil samples. Soil Biol Biochem 40(3):638-648

Kirsch RD, Joly E (1998) An improved PCR-mutagenesis strategy for two-site mutagenesis or sequence swapping between related genes. Nucleic Acids Res 26(7):1848-1850

Komori H, Higuchi Y (2015) Structural insights into the $\mathrm{O} 2$ reduction mechanism of multicopper oxidase. J Biochem 158(4):293-298

Komori H, Kajikawa T, Kataoka K, Higuchi Y, Sakurai T (2013) Crystal structure of the CueO mutants at Glu506, the key amino acid located in the proton transfer pathway for dioxygen reduction. Biochem Biophys Res Commun 438(4):686-690

Leis B, Angelov A, Liebl W (2013) Screening and expression of genes from metagenomes. Adv Appl Microbiol 83:1-68

Li Z, Kessler W, van den Heuvel J, Rinas U (2011) Simple defined autoinduction medium for high-level recombinant protein production using T7-based Escherichia coli expression systems. Appl Microbiol Biotechnol 91(4):1203-1213

Loncar N, Bozic N, Lopez-Santin J, Vujcic Z (2013) Bacillus amyloliquefaciens laccase-from soil bacteria to recombinant enzyme for wastewater decolorization. Bioresour Technol 147:177-183
Malmstrom BG (1982) Intermediates in the reduction of dioxygen y laccase and cytochrome c oxidase. Adv Exp Med Biol 148:87-94

Marchler-Bauer A, Derbyshire MK, Gonzales NR, Lu S, Chitsaz F, Geer LY et al (2015) CDD: NCBI's conserved domain database. Nucleic Acids Res 43(Database issue):D222-D226

Murugesan K (2003) Bioremediation of paper and pulp mill effluents. Indian J Exp Biol 41(11):1239-1248

Nasoohi N, Khajeh K, Mohammadian M, Ranjbar B (2013) Enhancement of catalysis and functional expression of a bacterial laccase by single amino acid replacement. Int J Biol Macromol 60:56-61

Nossal NG, Heppel LA (1966) The release of enzymes by osmotic shock from Escherichia coli in exponential phase. J Biol Chem 241(13):3055-3062

Palonen H, Viikari L (2004) Role of oxidative enzymatic treatments on enzymatic hydrolysis of softwood. Biotechnol Bioeng 86(5):550-557

Pardo I, Camarero S (2015) Laccase engineering by rational and evolutionary design. Cell Mol Life Sci 72(5):897-910

Peter MG, Wollenberger U (1997) Phenol-oxidizing enzymes: mechanisms and applications in biosensors. EXS 80:63-82

Prins A, Kleinsmidt L, Khan N, Kirby B, Kudanga T, Vollmer J et al (2015) The effect of mutations near the T1 copper site on the biochemical characteristics of the small laccase from Streptomyces coelicolor A3(2). Enzyme Microb Technol 68:23-32

Rivera-Hoyos CM, David Morales-Alvarez E, Poutou-Pinales RA, Marina PedrozaRodriguez A, Rodriguez-Vazquez R, Delgado-Boada JM (2013) Fungal laccases. Fungal Biol Rev 27(3-4):67-82

Roberts SA, Weichsel A, Grass G, Thakali K, Hazzard JT, Tollin G et al (2002) Crystal structure and electron transfer kinetics of $\mathrm{CueO}$, a multicopper oxidase required for copper homeostasis in Escherichia coli. Proc Natl Acad Sci USA 99(5):2766-2771

Ruijssenaars HJ, Hartmans S (2004) A cloned Bacillus halodurans multicopper oxidase exhibiting alkaline laccase activity. Appl Microbiol Biotechnol 65(2):177-182

Sharma P, Goel R, Capalash N (2007) Bacterial laccases (Article). World J Microbiol Biotechnol 23(6):823-832

Si W, Wu Z, Wang L, Yang M, Zhao X (2015) Enzymological characterization of Atm, the first Laccase from Agrobacterium sp. S5-1, with the ability to enhance in vitro digestibility of maize straw. PLoS ONE 10(5):e0128204

Singh SK, Roberts SA, McDevitt SF, Weichsel A, Wildner GF, Grass GB et al (2011) Crystal structures of multicopper oxidase CueO bound to copper(I) and silver(I): functional role of a methionine-rich sequence. J Biol Chem 286(43):37849-37857

Solomon El, Augustine AJ, Yoon J (2008) $\mathrm{O} 2$ reduction to $\mathrm{H} 2 \mathrm{O}$ by the multicopper oxidases. Dalton Trans 252(30):3921

Su J, Bao P, Bai T, Deng L, Wu H, Liu F et al (2013) CotA, a multicopper oxidase from Bacillus pumilus WH4, exhibits manganese-oxidase activity. PLoS ONE 8(4):e60573

Suzuki T, Endo K, Ito M, Tsujibo H, Miyamoto K, Inamori Y (2003) A thermostable laccase from Streptomyces lavendulae REN-7: purification, characterization, nucleotide sequence, and expression. Biosci Biotechnol Biochem 67(10):2167-2175

Thurston CF (1994) The structure and function of fungal laccases. Microbiology 140(1):19-26

Tian J, Wang P, Huang L, Chu X, Wu N, Fan Y (2013) Improving the thermostability of methyl parathion hydrolase from Ochrobactrum sp. M231 using a computationally aided method. Appl Microbiol Biotechnol 97(7):2997-3006

Tian J, Woodard JC, Whitney A, Shakhnovich El (2015) Thermal stabilization of dihydrofolate reductase using monte carlo unfolding simulations and its functional consequences. PLoS Comput Biol 11(4):e1004207

Ukkonen K, Mayer S, Vasala A, Neubauer P (2013) Use of slow glucose feeding as supporting carbon source in lactose autoinduction medium improves the robustness of protein expression at different aeration conditions. Protein Expr Purif 91(2):147-154

Zeng J, Lin XG, Zhang J, Li XZ, Wong MH (2011) Oxidation of polycyclic aromatic hydrocarbons by the bacterial laccase CueO from E. coli. Appl Microbiol Biotechnol 89(6):1841-1849

Zeng J, Zhu Q, Wu Y, Lin X (2016) Oxidation of polycyclic aromatic hydrocarbons using Bacillus subtilis CotA with high laccase activity and copper independence. Chemosphere 148:1-7

Zhao H, Zhou F, Qi Y, Dziugan P, Bai F, Walczak P et al (2013) Screening of Lactobacillus strains for their ability to bind benzo(a)pyrene and the mechanism of the process. Food Chem Toxicol 59:67-71 